\title{
A CAPITAL CUSTOM: VICTORIA AND THE NEW ZEALAND LEGAL TRADITION
}

\author{
Geoff McLay*
}

\begin{abstract}
This is the revised text of Geoff McLay's inaugural lecture given in the Council Chamber at Victoria University of Wellington on 7 June 2011. In the lecture, Professor McLay examines three defining themes of the New Zealand legal tradition and Victoria's contribution to it: (1) that New Zealand has been, and will continue to be a small place, but linked to a much wider legal world; (2) that the divide between public law and private law is both profoundly important, and at the same time, an illusion; and (3) that New Zealand academic lawyers have sometimes held an unnecessarily narrow view of what counts as law, and that particular legal academics might cast their attention a little wider. The lecture itself can be viewed at <http://mdsweb.vuw.ac.nz/Mediasite/Catalog/〉.
\end{abstract}

Chancellor, Vice-Chancellor.

Before I begin I would like to acknowledge my family: my wife Helen, our children Tom, Sam and Lizzie (who are at home tonight), my parents and parents-in-law. I know that I would not be here without them.

I would also like to acknowledge the presence of the Minister of Justice. It is an honour that the Minister is here; it is always a pleasure to see Simon Power. I would also like to say how honoured I am that the senior and junior law officers of the Crown are here (the Attorney-General, Christopher Finlayson and the Solicitor-General, David Collins QC). I have known both for a very long time, and both have helped me enormously. I am similarly honoured that so many judges, including the Chief Justice, have come tonight; we are very lucky to have so many judges that are an active part of our community.

On such occasions, and especially given the topic of tonight's lecture, it is important to acknowledge those who went before me and whom I never met, including John Thomas and

* Professor of Law, Victoria University of Wellington; Commissioner, New Zealand Law Commission. The views are my own. I would like to thank Olivia Krakosky for her help in editing this article, and the editors for their comments. 
Quentin Quentin-Baxter; and those whom I was lucky enough to know, or to at least have met, but who have now gone - Colin Aikman, Shirley Smith, ID Campbell, and sadly now, Dr George Barton.

I would like to thank those who are still at, or who have recently passed through, the Faculty and have been my colleagues. I especially acknowledge my Dean Brian Brooks, who hired me, Virginia Grainer, who supported me, Matthew Palmer, who put up with me, and Tony Smith, who has promoted me, together with the Dean during my time as a student, Tony Angelo.

\section{INTRODUCTION}

In his introduction the Vice-Chancellor said that I like to describe myself as the "last of the generalists". Obviously, I would like to disclaim the obvious pretentiousness of describing oneself as either being the last of something or as having achieved anything like "generalist" status. Most importantly, I would not like to devalue, at all, those amongst my colleagues who would prefer to describe themselves as specialists in particular areas. With specialism comes a degree of competency, which, I fear, I have never quite achieved.

I have, though, been greatly enamoured by Isaiah Berlin's distinction between foxes and hedgehogs, which has become perhaps just a little too fashionable of law: ${ }^{1}$

There is a line among the fragments of the Greek poet Archilochus which says: "The fox knows many things, but the hedgehog knows one big thing." ... [T]here exists a great chasm between those, on one side, who relate everything to a single central vision, one system, less or more coherent or articulate, in terms of which they understand, think and feel ... and, on the other side, those who pursue many ends, often unrelated to and even contradictory, connected, if at all, only in some de facto way, for some psychological or physiological cause, related to no moral or aesthetic principle. ... The first kind of intellectual and artistic personality belongs to the hedgehogs, the second to the foxes.

As the Vice-Chancellor said in his introduction, I have taught a great deal of subjects, and have tried to write on a number of them. Sometimes this must have been to the frustration of my colleagues both here and other places, who must have seen me as somewhat of a parvenu, skipping over nuances somewhat blithely. It is amongst the many things that my colleagues have had to put up with for so many years.

What I would like to say about my career as a member of the Faculty here is that I have been a magpie of sorts, seeking shiny titbits in a vast array of different subjects, but, I fear, adding very little of my own to the collection.

1 Isaiah Berlin "The Hedgehog and the Fox: An Essay on Tolstoy's View of History" in Henry Hardy and Roger Hausheer (eds) The Proper Study of Mankind: An Anthology of Essays (Chatto \& Windus, London, 1997) 436 at $436-437$ (citations omitted). 
What I have really been interested in over all of these diverse subjects is the nature of the New Zealand legal tradition or common law - does one exist, what does it mean to say that there is one, and where would you find it?

In many ways the two generations that preceded me at this law school - as indeed the two generations that preceded us since the Second World War in public life generally in New Zealand were engaged in defining a distinct New Zealand identity. Our generation, by way of contrast, starts from the assumption that there is a separate New Zealand in the world, that it is not defined by anywhere else, and that first and foremost we are New Zealanders who would never dream of calling somewhere else home or giving special deference to something because it comes from a particular place overseas.

But scholars in my generation have become interested in issues of identity and connection, and emphasise that we are not completely our own creation. However much we may wish it, our culture is not just of this place, and this is especially so of our legal culture. For the last several years, I have been teaching the law of torts with the aim not of teaching New Zealand common law, nor with the aim of creating New Zealand lawyers, but rather of teaching English common law as part of a tradition of more than 50 countries.

My basic theme for tonight is that legal tradition matters. That should not surprise you coming from someone who is a professor of law and holds a warrant from the Governor-General as a Law Commissioner: ${ }^{2}$

(a) to take and keep under review in a systematic way the law of New Zealand:

(b) to make recommendations for the reform and development of the law of New Zealand.

But I would make a bigger claim: we live in a country where even those who disagree with what the law is, or with what is done through the law, argue by reference to what is just or legal. It is easy to forget just how contingent the development of such a culture can be, and how fragile it has proved in other places.

I certainly agree that it is dangerous for legal historians to suggest that the only thing wrong with our history is that things were not done quite as they ought to have been done, or that things have been somehow slightly misunderstood. Nor do I go so far as to claim that the most important thing about New Zealand is a culture of legality, or that culture has always proved decisive, or that there are not clearly other important forces at play in both New Zealand's unique history, and in its present.

For my purposes I will organise my remarks into three (partially contradictory) sub-claims about the distinctiveness of the New Zealand legal tradition:

2 Law Commission Act 1985, s 5(1). 
(1) that New Zealand has been, and will continue to be, a small place, but one linked to a much wider legal world;

(2) that the divide between public law and private law is both profoundly important, and, at the same time, an illusion; and

(3) that while we have taken seriously the law business, the academy's definition of what counts as law has sometimes been unnecessarily narrow, and legal academics need to cast their attention a little wider.

There is obviously a fourth distinctive feature of New Zealand law (indeed some might properly say that it is the distinctive feature of New Zealand law as it is of New Zealand itself): the relationship between Māori and the law. Others are far more qualified to talk on that enormous subject. Many of you will have heard Richard Boast's wonderful lecture in this room three months ago, about the treaties between Māori and the Crown. ${ }^{3}$ There is such good work going on in this area: I mention, in particular, the project led by my colleague Māmari Stephens who is creating a lexicon of legal terms, ${ }^{4}$ which involves compiling an extraordinary wealth of Māori documentation, and which one suspects will take a lifetime to work through. I will also make reference to the fabulous work of my colleagues from the Lost Cases project - Dr Shaunnagh Dorsett ${ }^{5}$ and Dr Mark Hickford ${ }^{6}$ have done fascinating work on various aspects of Māori interaction with the law. ${ }^{7}$ And there are many others working in this area. To this valuable work I have very little to add other than my support and admiration.

\section{THE VICTORIA LEGAL TRADITION}

Before discussing my thoughts about the New Zealand legal tradition, I begin by talking about the legal tradition of Victoria University of Wellington (VUW or Victoria).

I would like to introduce some important people and their contributions by way of reference to the title pages of two copies of John Salmond's Essays in Jurisprudence and Legal History, ${ }^{8}$ which together say much of the unique continuities and discontinuities of the Law Faculty. The first copy

3 RB Boast "Treaties Nobody Counted On" (2011) 42 VUWLR 653.

4 See Māmari Stephens "The Legal Māori Dictionary (Pilot): Te Kaupapa Reo-a-Ture: Papakupu - He Tauira" (July 2010) Victoria University of Wellington <www.victoria.ac.nz>.

5 Shaunnagh Dorsett "Sworn on the Dirt of Graves: Sovereignty, Jurisdiction and the Judicial Abrogation of 'Barbarous' Customs in New Zealand in the 1840s" (2009) 30 The Journal of Legal History 175.

6 Mark Hickford Lords of the Land: Indigenous Property Rights and the Jurisprudence of Empire (Oxford University Press, Oxford, 2011).

7 To this I would add David V Williams A Simple Nullity? The Wi Parata Case in New Zealand Law and History (Auckland University Press, Auckland, 2011), published after my lecture.

8 John W Salmond Essays in Jurisprudence and Legal History (Stevens \& Haynes, London, 1891). 
of the book has the following letter taped inside the front cover (which is impeccably stamped by the VUW library as belonging to it):

Temuka Jan 12th 1892

Dear Sir Robert [Stout],

I send you herewith a little book which I have lately published. I am much afraid that the matter of it is

somewhat dry and indigestible, but you may perhaps be interested in it as being a local product. I called

at your house when in Dunedin at Christmas time but found you away.

With kind regards

I remain yours sincerely

John W Salmond

The second copy of the book was signed by the author on 27 May 1907, and by his student FA de la Mare. It was subsequently signed over by de la Mare to James Williams, "Professor of Law at Victoria University College in memory of his great predecessor" on 31 January 1942, who in turn signed the book over on 18 April 1967 to "Professor ILM Richardson, Head of the Department of English and New Zealand Law, on the occasion of his inaugural lecture, from a former Head of the Department".

John Salmond remains perhaps the most famous legal scholar that New Zealand has produced. But he might not necessarily have appreciated the appellation of today's lecture - at least during his time as a scholar. His great books are of (or, the wag might say, slightly before), his time. He was concerned with the systemisation of the common law that occurred in the late 19th and early 20th centuries. His great torts textbook is about the law of torts of England, not of the colonies in which he wrote: South Australia and New Zealand. ${ }^{9}$

Sir Robert Stout was perhaps New Zealand's most extraordinary legal and political figure: he was Premier, Chief Justice and founder of Victoria University College, and it is his library that the current VUW law library is built around. There was just enough of a hint of drama around his political career to make him a controversial figure, deserving of many biographies in addition to the published one ${ }^{10}$ and David Hamer's extraordinary Master's thesis. ${ }^{11} \mathrm{He}$ was Chief Justice for 27

9 See John W Salmond The Law of Torts: A Treatise on the English Law of Liability for Civil Injuries (Stevens \& Haynes, London, 1907).

10 Waldo Hilary Dunn and Ivor LM Richardson Sir Robert Stout: a biography (AH \& AW Reed, Wellington, 1961).

11 David Hamer "The Law and the Prophet: a Political Biography of Sir Robert Stout (1844-1930)" (MA Thesis, University of Auckland, 1960). 
years and his extraordinary corpus of over 1,400 reported decisions remains, with the exception of a chapter by Sir Ivor Richardson, ${ }^{12}$ unexplored.

Professor James Williams completed a $\mathrm{PhD}$ at Clare College at Cambridge on the Statute of Frauds ${ }^{13}$ and revived Salmond's contract law book. ${ }^{14}$ He left Victoria between 1942 and 1946 for a prestigious Chair at Sydney University, but returned to ultimately succeed Sir Thomas (Tommy) Hunter as Principal of Victoria University College, and became the first Vice-Chancellor of VUW. ${ }^{15}$ RB Cooke's reminiscence in Portrait of a Profession reads: ${ }^{16}$

Marked though his success as an administrator was, legal scholarship lost much when Dr Williams' interest was attracted away from it. In contrast, perhaps, to the traditional conception of an academic lawyer, he combines intellectual equipment of a high order with a keen appreciation of the realities of life and a balanced [judgement] ... Both as a scholar and as a teacher he would have graced any law school in the English-speaking world.

I will not presume to describe, in his presence, Sir Ivor Richardson's own contribution to the Faculty of which he was Dean, and his contribution to New Zealand law, but there was a change between Williams and Sir Ivor - the growing influence of the United States, in particular the Deanships of RO McGechan and Colin Aikman. ${ }^{17}$ In John Salmond's time, at the beginning of the 20th century, it was possible to talk of one common law tradition on both sides of the Atlantic and throughout the Empire. ${ }^{18}$ But by the Second World War major differences had divided that legal tradition. Realism and a rejection of the legal science and classificatory approach that scholars like John Salmond embodied had overtaken the American legal academy.

The American approach to law has been extremely fertile at Victoria and increasingly throughout New Zealand legal academia. One could lecture on its impact at length, but that has already been done by one of New Zealand's most distinguished American law graduates, Sir

12 Dunn and Richardson, above n 10.

13 James Williams The Statute of Frauds: Section Four, in Light of its Judicial Interpretation (Cambridge University Press, Cambridge, 1932).

14 John W Salmond (James Williams (ed)) Principles of the Law of Contracts (2nd ed, Sweet \& Maxwell, London, 1945).

15 See Rachel Barrowman Victoria University of Wellington 1899-1999: A History (Victoria University Press, Wellington, 1999) at 100-101.

16 Robin Cooke (ed) Portrait of a Profession: the Centennial Book of the New Zealand Law Society (Reed, Wellington, 1969) at 199-200.

17 Some of that story is covered in Geoff McLay "Toward a History of New Zealand Legal Education" (1999) 30 VUWLR 333.

18 See for example Richard Cosgrove Our Lady the Common Law: An Anglo-American Legal Community, 1870-1930 (New York University Press, New York, 1987). 
Kenneth Keith. ${ }^{19}$ The distinctive feature of law at Victoria, since the time of Robert McGechan and Colin Aikman, has been the mixing of traditions. The "legal system" course that has been part of Victoria's legal tradition for many years began life in a legal process book brought back by Colin Aikman from Wisconsin. That book and its focus on the process behind the compensation of accidents ultimately had a very real impact in the submissions made by members of this Faculty to the Woodhouse Commission in $1967^{20}$ of which I will speak again later. Indeed the history of the legal system course at Victoria would be worth a topic in its own right. Truth be told, although Victoria keenly engaged in the legal science tradition from the United States that lies behind the case method, it has never fully embraced the realism that followed it like a storm.

But we should also note the importance of FA (Froggy) de la Mare (1877-1960), who first got Salmond to sign the book (Essays in Jurisprudence and Legal History). Often when people tell stories of law faculties and legal traditions they omit the most important people; the students who make up much of the life of both. Mr de la Mare might stand, however imperfectly, for them. de la Mare, who practised in the Waikato, was the very definition of the engaged student and alumnus as a student he was the editor of the Old Clay Patch (a collection of poems about the College in its very early days), ${ }^{21}$ and as an alumnus he served for many years on the Senate of the University of New Zealand, and protested, quite rightly, the dismissal of Professor GW von Zedlitz during the First World War. His importance is reflected not only by his inclusion in the Dictionary of New Zealand Biography, but also by that entry having been written by the late Professor GP Barton. ${ }^{22}$ On a personal note, I also own a book previously owned by Mr de la Mare: Alpers' Cheerful Yesterdays, given to me by my father on my admission in 1992. ${ }^{23}$

\section{THE NEW ZEALAND LEGAL TRADITION}

\section{A What is Legal Tradition?}

What do I mean by legal tradition? The question "what is law?" is one that has been answered by legal philosophers and even by great poets like WH Auden. I am no kind of legal philosopher

19 Kenneth Keith "The Impact of American Ideas on New Zealand's Educational Policy, Practice and Theory: The Case of Law" (1988) 18 VUWLR 327.

20 Owen Woodhouse Compensation for personal injury in New Zealand: Report of the Royal Commission of Inquiry (Government Printer, Wellington, 1967) [Woodhouse Report].

21 FA de la Mare and S Eichelbaum The Old Clay Patch: a collection of verses written in and around Victoria (University) College, Wellington, NZ (Whitcombe \& Tombs, Wellington, 1910).

22 GP Barton "de la Mare, Frederick Archibald: Biography" (1 September 2010) The Dictionary of New Zealand Biography, Te Ara, The Encyclopedia of New Zealand <www.TeAra.govt.nz>.

23 OTJ Alpers Cheerful Yesterdays (John Murray, London, 1928). 
and I'm certainly not WH Auden, who famously compared law to love. ${ }^{24}$ The nearest a satisfactory explanation of what law is comes to my mind from Brian Simpson's great essay "The Common Law and Legal Theory", in which he suggests that law "consists of a body of practices observed and ideas received by a caste of lawyers". ${ }^{25}$ The common law in this view becomes less a system of rules and more a system of customary understandings as to how particular disputes can be resolved and differences reconciled.

\section{B New Zealand's Legal System as a Small One Within a Larger Universe}

The original aim of our Lost Cases project was to collect all superior court decisions in New Zealand until the founding of the official series of The Law Report in 1882. In fact the sheer weight of judicial decisions meant that we got only as far as 1870. As of the date of this lecture, the project has catalogued the following:

3,461 cases, made of:

- 3,382 Supreme Court cases;

- 78 Court of Appeal cases;

- 1 Vice Admiralty case

Consisting of:

- $\quad 2,249$ criminal cases;

- 1,153 civil cases; and

- 59 public law cases.

This project began with the purpose of discovering and preserving judicial decisions. The project took seriously the contention that if New Zealand is to have its own law, we should be interested in finding out how, in fact, our predecessors dealt with the founding of a New Zealand legal system, and how they adopted, and adapted, doctrines from their own homes. The essays

24 See WH Auden "Law, Like Love" in WH Auden Collected Shorter Poems 1927-1957 (Faber and Faber, London, 1966) 154 at 156 :

[Law] [1]ike love we don't know where or why,

Like love we can't compel or fly,

Like love we often weep,

Like love we seldom keep.

See also Sandra Petersson "Poetic Justices and the Legalities of Love" (2000) 31 VUWLR 103.

25 AWB Simpson "The Common Law and Legal Theory" in AWB Simpson Legal Theory and Legal History: Essays on the Common Law (The Hambledon Press, London, 1987) 359 at 376. 
published so far on the cases show the varied and almost inexhaustible material that might be mined by scholars from any number of disciplines.

Through the hard work of our research fellow Megan Simpson and the leadership of our colleague Dr Shaunnagh Dorsett, the project has uncovered an extraordinary wealth of information not just about famous court cases, but also about the operation of the courts in early colonial New Zealand. ${ }^{26}$ If there is an overall impression that can be gained from reading over the transcripts that we have assembled, and the judicial notebooks that we have photographed, it is of an abiding seriousness of enterprise. There is also a sheer diversity of material. This can perhaps be illustrated by the title page of the Victoria University of Wellington Law Review (VUWLR) issue that featured the papers presented to the Lost Cases Conference more than a year ago. ${ }^{27}$ The subjects range from intricate pleading points showing the very complexity in setting up courts from scratch; ${ }^{28}$ to significant constitutional issues regarding what effect the disallowance of a New Zealand ordinance would have on those who were affected by the ordinance ${ }^{29}$ to the very starting date of English law in New Zealand law; ${ }^{30}$ and to the importance of whaling in the development of law that reflected commercial practices. ${ }^{31}$ There are, of course, a number of papers dealing with the relationship between land, Māori, and the courts, and there is an essay describing Richard Boast's soon-to-be published collection of Māori Land Court decisions. ${ }^{32}$ The issue also features the work of Megan Simpson $^{33}$ and Professor Charlotte MacDonald ${ }^{34}$ which points to the wider significance of the early

26 See Victoria University of Wellington "New Zealand's Lost Cases" <www.victoria.ac.nz/law/nzlostcases>

27 Victoria University of Wellington Special Issue: New Zealand Leading Cases (2010) 41 VUWLR 291.

28 Shaunnagh Dorsett "Making Up the Issue: The Judges' Role in Formulating Actions in the (New Zealand) Crown Colony Period - Pharazyn v Smith (1844)" (2010) 41 VUWLR 427.

29 Damen Ward "Legislation, Repugnancy and the Disallowance of Colonial Laws: The Legal Structure of Empire and Lloyd's Case (1844)" (2010) 41 VUWLR 381.

30 David V Williams "The Pre-History of the English Laws Act 1858: Mcliver v Macky (1856)" (2010) 41 VUWLR 361

31 Stuart Anderson "Commercial Law on the Beach: Shore Whaling Litigation in Early Colonial New Zealand: Macfarlane v Crummer (1845)" (2010) 41 VUWLR 453.

32 RB Boast "Contextualising the Decisions of the Native Land Court: The Chatham Islands Investigations of 1870" (2010) 41 VUWLR 623. The first volume is at the time this goes to print, about to go to print itself RB Boast The Native Land Court 1862-1887: A Historical Study, Cases and Commentary (Thomson Reuters, Wellington, 2012).

33 Megan Simpson "The Action for Breach of Promise of Marriage in Early Colonial New Zealand: Fitzgerald v Clifford (1846)" (2010) 41 VUWLR 473.

34 Charlotte MacDonald "Land, Death and Dower in the Settler Empire: the Lost Cause of 'The Widow's Third' in Nineteenth-Century New Zealand" (2010) 41 VUWLR 493. 
court cases for social historians. The project was very generously funded by the New Zealand Law Foundation, who I hope are as proud of it as we are.

But the cases are not just examples of the development of New Zealand's indigenous common law. They represent something far richer. Up until the last few years, legal scholars were perhaps somewhat shy of the "Empire". For people whose enterprise was establishing the distinctive nature of their only national culture, references to Empire were not only perhaps counter-productive but also passé. The Empire may not quite have struck back, but it has made a bit of a comeback. Throughout the common law world there is a growing appreciation of the complex legal machinery of the Empire and the way in which English common law has been moulded by colonial experiences. There is a growing emphasis on connections between the legal personalities of the Empire, who sometimes floated from colony to colony, sometimes having outstayed their welcome in one to invent themselves anew in the next. ${ }^{35}$ Moreover, there is a growing awareness of the commonalities of the problems faced in settler societies and the legal apparatus used to deal with those problems. There is far greater sophistication in understanding that the law was not just informed from the centre, but also that modifications and innovations sometimes made their way back to the centre.

Perhaps I can use one example of these connections from my own work. What interested me about Crown liability in the 19th century was not just the reform of the old, common law maxim, "the King can do no wrong", but also the way in which very different places had to deal with the same basic legal doctrine, and the way in which local realities interacted to create new law. On the face of things there is very little in common between the sinking of a slaving ship off the East Coast of Africa by Captain Sholto Douglas in $1862^{36}$ and a horse buggy accident on the Otago Peninsula caused by a fallen telegraph wire in the late $1880 \mathrm{~s} .{ }^{37}$ The connection between the cases was that in the former, the English courts accepted that the British Navy could not be sued because the Crown could do no wrong. ${ }^{38}$ In the latter, by allowing the mercers to sue the Crown in New Zealand in the guise of the Post Office, the courts held that the legislature, drawing in part from the legislatures in the other Australasian colonies, had granted sufficient personality to the Crown to enable it to be sued. While the Crown did little in England apart from defending the realm, the Crown in the colonies was a critical economic actor, and the ability to sue it would not only create injustices for others but also inconvenience the Crown itself. I use the word "inconvenience" because the

35 See for example John McLaren Dewigged, Bothered, and Bewildered: British Colonial Judges on Trial, 1800-1900 (University of Toronto Press, Toronto, 2010).

36 Tobin v The Queen (1864) 16 CB (NS) 310, 143 ER 1148 (Comm Pleas).

37 Mercer $v$ The Queen SC Wellington, 20 July 1881 reported in The Otago Daily Times (Dunedin, 21 July 1881 ) at 3; see also Stuart Anderson "'Grave Injustice', 'despotic privilege': the insecure foundations of Crown liability for torts in New Zealand" (2009) 12 Otago L Rev 1.

38 Tobin v The Queen, above n 36. 
government of any developing country needs to be able to assure those with whom it does business that it will make good in the event of things going wrong. The Australasian statutes which reformed the law in the colonies, while not exactly models for the English reforms in 1947, were often cited as justification that the sky would not fall if the Crown were subject to its own laws.

In my own essay in the Lost Cases volume of the VUWLR I explore this connection in relation to public works integration contracts, something which is not quite as dry as it obviously sounds tonight. ${ }^{39}$ The most important "case" in New Zealand was a decade long struggle by the English firm Brogden and Sons to bring claims against the Government in relation to contracts for rail constructions. Even more interesting jurisprudentially was the trouble that the Crown's lack of personality created for it when it wanted to sue (or when others wanted to sue it) in England for "breaches" of obligations incurred during assisted immigration. The most dramatic of those breaches was the loss of life of passengers aboard the Cospatrick that burst into flames off the coast of South America. The legal question was: how could a Crown that did not exist in the English courts recover money from a shipping company which had failed to deliver the immigrants that the New Zealand Government had paid them to deliver? ${ }^{40}$

The lesson of the Lost Cases project was that those who are engaged in the process of creating an explicitly New Zealand law ought to look at the experience of doing just that, which we uncovered in the earlier part of New Zealand's legal history. There is a legitimate debate still to be had as to the degree to which New Zealand ought to expressly develop its own common law, and I would suggest tonight that New Zealand is yet to develop a satisfactory model for doing so. Reference might be made to the difficult case of Invercargill City Council v Hamlin (Hamlin), which to my mind presents two very different models of how and when New Zealand ought to develop its law. ${ }^{41}$ That case involved an Invercargill house's bad foundations. Hamlin is now looked upon as the foundational case for council liability for badly inspected, and now leaking, homes. The issue in front of the Court of Appeal was whether to follow a decision, Murphy v Brentwood District Council (Murphy), in which the House of Lords very clearly said that there could be no liability in English law for any inspection by a local authority. ${ }^{42}$ The two leading judgments, written by Sir

39 Geoff McLay "The Problem with Suing Sovereigns: Sloman v Governor and Government of New Zealand (1876)" (2010) 41 VUWLR 404.

40 See Sloman v Governor and Government of New Zealand (1876) 1 CPD 563 (Comm Pleas); notes on Featherston v Shaw, Saville and Co (QB) Archives New Zealand, Wellington, IM 5 4.2, no 126, Micro 5842 .

41 Invercargill City Council v Hamlin [1994] 3 NZLR 513 (CA). The cases are discussed in more detail in Geoff McLay "Legal Doctrine, the Leaky Homes Crisis and the Limits of Judicial Law-Making" in Steve Alexander and others The Leaky Buildings Crisis: Understanding the Issues (Brookers, Wellington, 2011) 1 at $3-17$.

42 See Murphy v Brentwood District Council [1991] 1 AC 398 (HL). 
Robin Cooke and Sir Ivor Richardson, present different models of how one might go about answering that question.

Sir Ivor's judgment sought to provide a justification based on the different circumstances of the two countries. However successful those justifications look after 15 -odd years, the implication is perhaps that rather than seeking to depart from the common law in England simply because we might disagree with it, we ought to look for reasons that require a New Zealand departure. Sir Robin's judgment, although most famous for its clarion call to develop indigenous New Zealand law, ${ }^{43}$ appears to be a contribution to the debate over the shape of the common law in general. His Honour was more concerned about the way in which Murphy had departed from a common law consensus, and his judgment appears to be trying to put the common law in general back on the right track. It seems to me that both models are important ways of talking about the development of the common law, but they will sometimes lead to importantly different conclusions.

There are real costs in seeking to achieve the "best" rule, if it means departing from, or potentially departing from, the more mainstream position on any given contentious common law issue. This harks back to the theme of smallness. The common law depends on cases. The reality is that we do not have enough common law decisions to cover all that a comprehensive system needs to cover. Unquestionably, it has to be a good thing that the House of Lords, or now the Supreme Court of the United Kingdom, does not automatically decide New Zealand legal policy. However, we need a more sophisticated reception of rules that will guide us in receiving, or rejecting, overseas law.

The same point might be made of the development of New Zealand statutes. No one in this room would seriously countenance the unequivocal adoption of overseas statutes simply because they had been passed in other jurisdictions. But the reality is that a small jurisdiction needs to seriously consider the wisdom of "ground up" development of statutes, which might potentially be more appropriately imported from other jurisdictions. Differences in legislation should reflect policy

43 Invercargill City Council v Hamlin, above n 41, at 523:

One need hardly labour that Judges in different common law countries may legitimately differ in their conclusions in such a field.

...

While the disharmony may be regrettable, it is inevitable now that the Commonwealth jurisdictions have gone on their own paths without taking English decisions as the invariable starting point. The ideal of a uniform common law has proved as unattainable as any ideal of a uniform civil law. It could not survive the independence of the United States; constitutional evolution in the Commonwealth has done the rest. What of course is both desirable and feasible, within the limits of judicial and professional time, is to take into account and learn from decisions in other jurisdictions. It behoves us in New Zealand to be assiduous in that respect. 
that genuinely reflects different New Zealand circumstances, not just a desire to do things "better". Just one example which might serve to illustrate this point is that of the Copyright Act 1994. Arguably, there is a lot wrong with the United Kingdom Copyright Act, which we largely re-enacted in New Zealand in 1994, and it might be that some of the individual provisions could have been better drafted, or some of the policy issues better dealt with. But there are clear advantages in sharing a law with a major jurisdiction. It enables us to benefit from the not inconsiderable work undertaken by that jurisdiction in creating, interpreting and understanding the law. Rather than simply starting from scratch, there might be real merit in devoting energy to policy development only when it really matters in order to develop New Zealand-specific policy on matters that are of particular significance to New Zealand law.

\section{Public and Private Law - an Essential Difference, but Also an Illusory One}

My second and third points are about the relationship between public and private law in New Zealand.

One of the features of my career has been dabbling on both sides of the public and private law divide. There is no question that there are important differences between the law of the State and the law of private parties. There is also no question that things can be done differently in public law and private law and vice versa, and that those distinctions are important to maintain. It is inappropriate to treat private people as unnecessarily constrained by the same concerns with which the State is constrained. But there is often a harder version of the divide: that public policy is not to be considered when dealing with "private law".

One of the surprising jurisprudential events of the last two decades has been the re-emergence in Commonwealth countries of notions of the uniqueness of private law. ${ }^{44}$ Again, this could be a lecture in and of its own right. The American side of my legal education brings enormous scepticism to the claims of those who see private law as distinct. Despite the efforts of Allan Beever this divide between the "public" and the "private" has not been the approach in New Zealand, at least as far as tort law has been concerned. ${ }^{45}$

The division between private law and public law in this sense would have been one that was familiar to the legal tradition of which John Salmond was a part, but it is not one which convinces New Zealand lawyers nowadays. For instance, by and large New Zealand courts, in determining tort cases, continue to use the public policy considerations that necessarily surround such decisions. More importantly, the example of Accident Compensation has shown a uniquely New Zealand

44 The leading book is perhaps that by Ernest J Weinrib The Idea of Private Law (Harvard University Press, Cambridge (Mass), 1995).

45 See though Allan Beever Rediscovering the Law of Negligence (Hart Publishing, Oxford, 2007). 
public response to what other countries, and other academics, would consider to be problems of private law. This is as it should be. When I taught torts in the United States there was no pretence that tort law belonged - except perhaps in the most arcane areas - to private law, in the sense of being removed from public policy. It is properly about the important social and economic balancing of who bears what risk and who ought to compensate whom.

The revolution in thinking about the role of law in the domain of accidents is represented by the Woodhouse Report. ${ }^{46}$ Perhaps "the New Zealand legal classic", it is light years from John Salmond's textbook in which accidents are essentially legal events between two parties. As my friend Richard Gaskins explained during numerous visits to New Zealand, the true significance of Woodhouse lies not just in providing a compensation scheme but more in seeing accidents not as legal events between two parties but rather as social events. ${ }^{47}$

Some, of course, would not agree. When teaching torts at the University of Iowa College of Law I was confronted not just with the usual student scepticism of grand ideas, but with a rather startling observation from the back row that I was talking "communism". ${ }^{48}$ Indeed there is much to debate about Accident Compensation. It has been one of the important parts of my career to try to encourage legal academics to become as interested in debating Accident Compensation as our predecessors were in its creation. In one place I tried to explore why there is a relative paucity of New Zealand legal academic writing on the actual scheme; sometimes it seems that the nature of Accident Compensation passed somehow beyond academic lawyers. I think this is to be greatly regretted. It seems to me that in choosing to teach courses focused on the operation of the common law system, we have robbed students of much of the richness of New Zealand's unique experience. It is not that there are not legal questions in the operation of the scheme, it is that they are the kinds of questions that public lawyers ought to be asking in terms of accountability and administration the law, after all, shapes everything that the Accident Compensation Corporation does, and it matters that it does what it does as a public body. Sir Geoffrey Palmer, who was very much involved in bringing the Accident Compensation scheme to New Zealand, began the task by styling his post-ACC book Tort in Transition. ${ }^{49}$ On the whole we have done quite a poor job in figuring out where tort was transitioning to.

46 Woodhouse Report, above n 20.

47 See for example Richard Gaskins "Reading Woodhouse for the Twenty-First Century" [2008] NZ L Rev 1.

48 Some of that experience is discussed in Geoff McLay "Accident Compensation - What's the Common Law Got to Do With It?" [2008] NZ L Rev 55.

49 PD McKenzie and others Tort in Transition: a New Zealand collection of cases and materials on tort in the accident compensation era (Fourth Estate Books, Wellington, 1976). 
This leads me onto another observation that, with some very notable exceptions (most notably my now colleague Professor John Burrows $)^{50}$ New Zealand legal academics are not as interested in bureaucracy or the operation of Parliament and its statutes as they ought to be. The consequence of having a fast, if not quite the fastest, law-maker in the west, is that we have a lot of statute law, and one senses that as legal academics we have been somewhat uncomfortable on occasions both with the general phenomena of what Parliament does and the particulars of how it does it. It was not until I began attending meetings of the Legislation Advisory Committee (under the acting chairmanship of George Tanner QC), that I began asking myself even the most basic questions about how legislation is put together and about the processes that mould legislation. This is, perhaps, a portion of our American inheritance that we have not fully grasped. The reality is that the common law lives, as Guido Calabresi put it, "in the age of statutes."

\section{Look for Law in Other Places}

My third point or theme tonight is really an extension of the second. By and large the tradition of our law school and our scholarship has focused on the courts.

Often focusing on courts gives us the wrong impression of the forces shaping our legal system, and indeed, shaping individual cases. This is one of the key lessons that I learnt in my work on sovereign immunity. If one reads cases that appear to deny the possibility of liability in the law reports, one gets the impression that the Government was trying not to pay. Perhaps the most important thing that Brian Simpson taught me - and, many others - is to check the files, the newspapers and whatever other source you can. In fact what the files in some of those cases tell you is that the Government almost immediately decided to settle the case but was not prepared to have courts say that they had to. I think there is an important lesson to be learnt here: that just because you cannot go to court on a particular matter does not mean that there is no law in operation.

It seems to me that an important part of our "little" tradition has always been somewhat hidden from view in memoranda and opinions written by Crown lawyers outside the purview of the courts, which seek to limit what grounds of obligations to this difference are, what may be done, may not be done and the manner in which it may be done. Perhaps this is why we have such a poor impression of the way in which formal European law dealt with Māori.

One reason for focusing on the courts is that cases are generally publicly available. How do we study what went on or indeed what is currently going on? One of the great revelations of checking the files is just how much information there can be. Our colleague Mark Hickford has produced an extraordinarily detailed work which plots how legal advisers within government tried to deal legally

50 See for example JF Burrows and RI Carter Statute Law in New Zealand (4th ed, LexisNexis, Wellington, 2009)

51 Guido Calabresi A Common Law for the Age of Statutes (Harvard University Press, Cambridge (Mass), 1982). 
with Māori issues in the 19th century. ${ }^{52}$ Much more of this work needs to be done to keep a sense of what was really happening in the New Zealand legal tradition in the 19th and 20th centuries. Indeed Damen Ward and I have often discussed a project that would look for the "lost constitution".

\section{FUTURE PROJECTS}

I have two projects proceeding on an "as possible basis", designed to explore these three themes in a more concrete setting, but which are temporarily suspended as a result of my appointment to the Law Commission. One project is an annotated volume of Solicitor-General opinions, showing how the New Zealand legal practice developed within government. Many of the most remarkable opinions were, of course, written by the man whose books I discussed earlier, John Salmond, although this time in his role as Solicitor-General extraordinaire. One suspects that his major contribution to our tradition is to be found not in his textbooks, nor in his very brief time as a teacher at Victoria, or in the judgments that he wrote later as judge, but in the legislation he drafted, and the opinions that he wrote. My other project is even grander, a biography of Sir Robert Stout, the other man who I started tonight's lecture with. Much of what I have been speaking of here is, of course, the interaction between law and politics and the effect that they have on each other. Indeed that is the very gist of the career of Sir Robert Stout, who was exceptional as a lawyer, politician, judge and in many ways was the founder of our capital tradition.

\section{A FINAL THANKS}

I would like to end by thanking and acknowledging the support of my teacher, colleague and friend, Bill Atkin. Without his guidance on many occasions I am sure that I would not be here speaking to you tonight, and I am conscious of the debt that I owe him.

52 See Hickford, above $\mathrm{n} 6$. 